\title{
Isoprene-degrading bacteria associated with the phyllosphere of Salix fragilis, a high isoprene-emitting willow of the Northern Hemisphere
}

\author{
Lisa Gibson ${ }^{1 *}\left(\mathbb{D}\right.$, Andrew T. Crombie ${ }^{2}$, Niall P. McNamara ${ }^{3}$ and J. Colin Murrell ${ }^{\text {* }^{*}}$
}

\begin{abstract}
Background: Isoprene accounts for about half of total biogenic volatile organic compound emissions globally, and as a climate active gas it plays a significant and varied role in atmospheric chemistry. Terrestrial plants are the largest source of isoprene, with willow (Salix) making up one of the most active groups of isoprene producing trees. Bacteria act as a biological sink for isoprene and those bacteria associated with high isoprene-emitting trees may provide further insight into its biodegradation.

Results: A DNA-SIP experiment incubating willow (Salix fragilis) leaves with ${ }^{13} \mathrm{C}$-labelled isoprene revealed an abundance of Comamonadaceae, Methylobacterium, Mycobacterium and Polaromonas in the isoprene degrading community when analysed by $16 \mathrm{~S}$ rRNA gene amplicon sequencing. Metagenomic analysis of ${ }^{13} \mathrm{C}$-enriched samples confirmed the abundance of Comamonadaceae, Acidovorax, Polaromonas, Variovorax and Ramlibacter. Mycobacterium and Methylobacterium were also identified after metagenomic analysis and a Mycobacterium metagenome-assembled genome (MAG) was recovered. This contained two complete isoprene degradation metabolic gene clusters, along with a propane monooxygenase gene cluster. Analysis of the abundance of the alpha subunit of the isoprene monooxygenase, isoA, in unenriched DNA samples revealed that isoprene degraders associated with willow leaves are abundant, making up nearly $0.2 \%$ of the natural bacterial community.

Conclusions: Analysis of the isoprene degrading community associated with willow leaves using DNA-SIP and focused metagenomics techniques enabled recovery of the genome of an active isoprene-degrading Mycobacterium species and provided valuable insight into bacteria involved in degradation of isoprene on the leaves of a key species of isoprene-emitting tree in the northern hemisphere.
\end{abstract}

Keywords: Isoprene, Climate, Isoprene monooxygenase, DNA stable isotope probing, Salix fragilis, Willow tree, isoA

\section{Introduction}

Isoprene (2-methyl-1,3-butadiene) is a biogenic volatile organic compound (BVOC) that is emitted globally at a rate of $\sim 500 \mathrm{Tg}$ year $^{-1}[1]$ making isoprene one

*Correspondence: lisa.gibson@uea.ac.uk; j.c.murrell@uea.ac.uk

${ }^{1}$ School of Environmental Sciences, University of East Anglia, Norwich Research Park, Norwich NR4 7TJ, UK

Full list of author information is available at the end of the article of the most prevalent atmospheric BVOCs, second only to methane $[1,2]$. Due to its volatile nature as a reactive diene, isoprene plays a complex role in atmospheric chemistry and is thought to contribute both warming and cooling effects on the Earth's climate. Isoprene reacts readily with hydroxyl radicals $(\mathrm{OH})$, reducing the oxidative capacity of the atmosphere and increasing the residence time of other greenhouse gases like methane. In pristine environments with low levels of nitrogen oxides original author(s) and the source, provide a link to the Creative Commons licence, and indicate if changes were made. The images or other third party material in this article are included in the article's Creative Commons licence, unless indicated otherwise in a credit line to the material. If material is not included in the article's Creative Commons licence and your intended use is not permitted by statutory regulation or exceeds the permitted use, you will need to obtain permission directly from the copyright holder. To view a copy of this licence, visit http://creativecommons.org/licenses/by/4.0/. The Creative Commons Public Domain Dedication waiver (http://creativeco mmons.org/publicdomain/zero/1.0/) applies to the data made available in this article, unless otherwise stated in a credit line to the data. 
$\left(\mathrm{NO}_{\mathrm{x}}\right)$, isoprene reacts directly with $\mathrm{OH}$, thus reducing its overall tropospheric level. However in the presence of higher NOx, common in highly populated urban areas, the oxidation of isoprene results in the production of $\mathrm{NO}_{2}$ via photolysis, which in turn increases ozone levels and thus can have a detrimental impact on air quality and human health [3, 4]. In other circumstances, the products of isoprene oxidation in the atmosphere can act as cloud condensation nuclei which then lead to an increase in cloud formation and contribute to atmospheric cooling [5].

The production of cis-polyisoprene (synthetic rubber) is the main source of anthropogenic emissions of isoprene [6] but the bulk of isoprene produced arises from the natural environment. Biosynthesis of isoprene is widespread and can be observed in some species of bacteria, fungi, algae and animal in both aquatic and terrestrial environments [7-14], however, about $90 \%$ of isoprene production originates from terrestrial plants and particularly trees $[12,15]$. Isoprene synthase is the enzyme responsible for isoprene production in plants, although its presence and activity can vary significantly, even between trees of the same genus [16-19]. In trees that emit isoprene, it is produced in the chloroplast via the methyl-erythritol 4-phosphate (MEP) pathway [20]. The isoprene synthase enzyme is responsible for converting dimethylallyl diphosphate (DMADP) to isoprene. In some cases, $1-2 \%$ of the total carbon fixed by the plant is converted to isoprene, making its production a significant investment on the part of the plant $[21,22]$. However, the exact reason why plants produce isoprene is not yet fully understood. It has been reported that isoprene improves the resilience of plants to oxidative, thermal and biotic stresses [22-25], however the mechanisms for these processes have yet to be fully elucidated. In terms of thermo-tolerance, it was previously thought that isoprene could intercalate into thylakoid membranes and improve their stability under heat stress $[26,27]$. However, recent studies show that due to the highly volatile nature of isoprene and its inability to dissolve well into cellular components, isoprene is unable to accumulate in chloroplastic membranes at a concentration high enough to provide any significant impact on membrane stability [28]. A review by Lantz et al. [29] suggests that isoprene may play a role in gene expression, although direct evidence for this theory is still limited.

The production and impact of isoprene on the atmosphere has long been studied, but the removal of isoprene via biological processes is a mechanism that is still relatively unexplored. Field chamber studies showed that temperate forest soils can rapidly deplete isoprene from $\sim 400 \mathrm{ppbv}$ to below a $5 \mathrm{ppbv}$ detection limit [30, 31]. Experiments utilising a continuous-flow method showed that temperate forest soil systems were also effective at consuming lower concentrations of isoprene, with as little as 2 ppbv isoprene being utilised [32]. Bacterial strains capable of growth with isoprene as their sole carbon source have been isolated from soil, phyllosphere, and aquatic environments [33-40], reviewed in [41]. These earlier studies found most success in isolating Gram-positive Actinobacteria such as Rhodococcus, Gordonia and Mycobacterium. Recently however, targeted isolation techniques have resulted in the isolation of novel Gram-negative Proteobacteria such as Sphingopyxis, Variovorax and Ramilibacter, diversifying the collection of validated isoprene degrading bacteria [42].

All extant isoprene degrading bacteria use the enzyme isoprene monooxygenase (IsoMO) to oxidise isoprene. IsoMO, encoded by the genes, iso $A B C D E F$, catalyses the first step of the isoprene degradation pathway. Adjacent genes isoGHIJ encode a CoA transferase, dehydrogenase and two glutathione transferases, and glutathione biosynthesis genes and other putative genes involved in the subsequent steps of isoprene metabolism (recently reviewed in $[41,43]$ are also in the same cluster. The gene encoding the $\alpha$-subunit of the IsoMO, iso $A$, is highly conserved amongst isoprene degrading bacteria, making it an excellent functional gene probe when investigating the presence, distribution, and diversity of isoprene degrading bacteria in the environment. This approach (recently reviewed in [44]) has been utilised previously in combination with DNA stable isotope probing (DNA-SIP) [45, 46] to investigate isoprene degrading communities in a cultivation-independent manner [36, 37, 39-42, 47]. The genetic information recovered, and the isolates obtained from these studies allowed for the development of new, robust gene probes to examine the diversity of isoprene degradation genes recovered from environmental samples [48].

Willow species are common in the northern hemisphere and are among the highest emitters of isoprene (emissions of up to $37 \mu \mathrm{g}$ g(dry weight) $\mathrm{h}^{-1}$ have been recorded) [49]. There are a number of willow species in the UK such as the Salix fragilis studied here, one of the larger species of Willow often found by rivers and lakes and frequently used to stabilise riverside soil [50]. Willow is also planted in high numbers as a short-rotation coppice (SRC) used for bioenergy, an example of which was also examined in this study [51-53].

Soil associated with willow species has previously been investigated for the presence of isoprene degrading bacteria [42] however, at $30 \mathrm{ppmv}$, the level of isoprene found in the intercellular spaces of leaves is orders of magnitude higher than atmospheric isoprene found at ground level, with the potential to select for a very different isoprenedegrading bacterial community than that found in bulk 
soil environments $[54,55]$. The aim of this study was to investigate the phyllosphere of willow using DNA-SIP and qPCR methods to identify the bacteria responsible for isoprene degradation on the leaves of a high-isopreneemitting tree in the Northern Hemisphere.

\section{Materials and methods}

\section{Isoprene DNA-SIP incubations and DNA extraction}

For SIP incubations, leaves (approximately $2.5 \mathrm{~m}$ above ground level) were removed from the south-facing side of a willow tree (Salix fragilis), located on the campus of the University of East Anglia. Cells were dislodged from leaves (approx. $5 \mathrm{~g}$ ) by ultrasound as described previously [40] except using a $1 / 2$ dilution of the minimal medium [56]. Cell pellets (retrieved by centrifugation and filtration as described [40]) were resuspended in $50 \mathrm{ml}$ minimal medium diluted as above and incubated in flasks $(2 \mathrm{~L}$ volume) with isoprene (either unlabelled (Sigma Aldrich, Gillingham, UK) or uniformly ${ }^{13} \mathrm{C}$-labelled, synthesised as described [39]) added to approx. 150 ppmv by injection of vapour through the septum and incubated with shaking $(150 \mathrm{rpm})$ at $25{ }^{\circ} \mathrm{C}$. Headspace isoprene concentrations were monitored by gas chromatography [37] and incubations with labelled or unlabelled substrate were carried out in triplicate. When isoprene was depleted, flasks were replenished once to the same isoprene concentration, and cells were harvested when the microcosms had consumed approx. $0.5 \mu \mathrm{mol}$ isoprene $\mathrm{ml}^{-1}$ (13-53 days). Cells were harvested by centrifugation $\left(12,000 \times g, 20 \mathrm{~min}, 15^{\circ} \mathrm{C}\right)$ and the cell pellet stored at $-20^{\circ} \mathrm{C}$ prior to DNA extraction.

\section{Nucleic acid extraction}

DNA was extracted using the FastDNA spin kit for soil (MP Biomedicals, Solon, OH, USA) following the manufacturer's instructions, except using two bead beating treatments (each $40 \mathrm{~s}$, speed 6.0) in the FastPrep instrument. DNA was quantified using a Qubit 2.0 fluorometer (Thermo Fisher, Waltham, MA, USA) following the manufacturer's instructions.

\section{Stable isotope probing}

${ }^{13} \mathrm{C}$-labelled and unlabelled DNA were separated by density gradient ultracentrifugation and fractionation (12 fractions per sample) as described previously [39]. The relative proportion of DNA retrieved from each fraction was plotted against buoyant density, quantified by refractometry (Reichert AR200, Reichert Analytical Instruments, Buffalo, NY, USA), (Additional file 1: Fig. S1). Based on the data shown in Additional file 1: Fig. S1 the fractions containing ${ }^{13} \mathrm{C}$-labelled ("heavy") and unlabelled ("light") DNA were identified and used for analysis. Of the total DNA recovered from each ultracentrifugation tube, on average $1.2 \pm 0.47 \%$ was located in the heavy fractions of ${ }^{12} \mathrm{C}$-isoprene incubations, whereas $19.7 \pm 2.53 \%$ was recovered from the heavy fractions of ${ }^{13} \mathrm{C}$ incubations.

\section{Sequencing of DNA}

The bacterial communities of the timepoint zero samples together with the heavy and light fractions from ${ }^{12} \mathrm{C}$ and ${ }^{13} \mathrm{C}$-isoprene incubations were profiled by amplicon sequencing of the $16 \mathrm{~S}$ rRNA gene, generated using primers 0341F/0785R [57], following the Illumina $16 \mathrm{~S}$ Metagenomic Sequencing Library Preparation (2013) protocol [58]. Pooled libraries were sequenced using the Illumina MiSeq platform $(2 \times 250$ bp paired-end reads $)$ at the Centre for Genomic Research (CGR), University of Liverpool, UK. DNA from the heavy fractions of ${ }^{13} \mathrm{C}$-isoprene incubations was also sequenced by shotgun metagenomics. Library preparation (insert size $<500 \mathrm{bp}$ ) and sequencing were conducted by CGR using an Illumina HiSeq 2500 platform in high-output mode (v4) $(2 \times 125$ bp paired-end reads). Samples were processed with the use of the Nextera XT kit following the Nextera XT workflow [59] including an additional purification step with the use of Agencourt AMPure XP beads.

\section{$16 \mathrm{~S}$ rRNA gene amplicon sequencing}

16S rRNA gene amplicon sequencing data were analysed using the Bioconductor package DADA2 ([60]; version 1.6). Forward and reverse reads were trimmed by 33 and 37 nucleotides respectively to remove any adapter sequences and quality-filtered if their expected error was greater than two according to the DADA2 quality analysis. Sequences were then denoised using the estimated error rates and resultant reads were dereplicated. Subsequently, chimeric sequences were discarded and the DADA2 algorithm was used to infer individual amplicon sequence variants (ASVs). ASVs were then taxonomically identified with the use of the RDP rRNA database ([61]; version RDP trainset 18).

\section{Metagenomic analysis}

of The phylogenetic community as derived by rawmetagenomic reads was assessed via Kraken ([62]; version 1.1.1) and the results fed to Bracken (version 2.5; [63]) with a kmer length of 31 to determine relative abundance of each taxa. Metagenomic reads were processed and initial analysis carried out with various modules included in the MetaWRAP pipeline as described here ([64]; version 1.2.1). Sequencing results from the heavy fractions of the three ${ }^{13} \mathrm{C}$-isoprene enriched samples were pooled giving a total of $24,849,791$ reads and the subsequent assembly of these reads resulted in an N50 of 15,027 bp. To achieve this, raw, pooled reads were pre-processed with the use 
of the metaWRAP::Read_qc module with default settings, though the bmtagger step was skipped. Assembly was carried out with the metaWRAP::Assembly module utilising the assembler metaSPAdes.

Binning of metagenome assembled genomes (MAGs) was carried out simultaneously via the metaWRAP::Binning module using metaBAT2 ([65]; version 2.12.1), MaxBin2 ([66]; version 2.2.6) and CONCOCT ([67]; version 1.0.0) and the results for each compared in order to compile the MAGs of the highest quality from each. These MAGs were then reassembled to improve completion by mapping reads back to the assembled genomes. The completeness, strain heterogeneity and contamination of each MAG was assessed with CheckM (version 1.0.18; [68]) utilising the lineagespecific workflow. The metaWRAP::Classify bins module [63] was used to assign taxonomy to each MAG. MAGs of interest were functionally annotated with PROKKA ([69]; version 1.14.5) with default settings and the '-centre $X^{\prime}$ tag to generate appropriate contig names. MAG abundance was measured as genome copies per million reads. This measure was obtained by aligning reads to the entire indexed metagenomic assembly using the Quant_ bins::MetaWRAP module which then uses Salmon ([70]; version 0.14 .2 ) to estimate the abundance of each contig. The average abundance of each MAG is calculated by taking the length-weighted average of the MAG's contig abundance [71]. Annotated MAGs were investigated with the use of the Artemis genome browser [72]. MAGs were investigated for the presence of plasmid DNA with the use of the plasmidVerify script [73] developed by the Centre for Algorithmic Biotechnology, Saint Petersburg State University.

MAGs of interest were further analysed with the MiGA pipeline to obtain a higher resolution taxonomic classification to species level where possible [74].

\section{iso $A \mathrm{qPCR}$ analysis}

For qPCR analysis of isoprene degraders in the environment, samples were obtained from a commercial farm in Lincolnshire, NE England $\left(53^{\circ} 18^{\prime} 55^{\prime \prime} \mathrm{N} ; 0^{\circ} 34^{\prime} 40^{\prime \prime} \mathrm{W}\right)$ on adjacent plantations of willow SRC (Salix viminalis), miscanthus (Miscanthus $x$ giganteus) and poplar (Populus nigra). Three different trees each made up the replicates for poplar and willow samples. From each of these replicates, three samples per tree were made up of $2 \mathrm{~g}$ of collected leaf material taken from different sides of each tree. Miscanthus leaves were taken from six varying locations within the plantation area. DNA was extracted from cells associated with leaves as described earlier for DNA-SIP experiments. Extracted DNA was cleaned of any impurities that may have inhibited PCR activity with a second run of the FastDNA spin kit for soil (MP
Biomedicals, Solon, OH, USA) following the manufacturer's instructions. DNA was quantified as described earlier.

iso $A$ sequence abundance in unenriched environmental samples were quantified by qPCR targeting the iso $A$ gene using primers isoA14F and isoA511R [48]. qPCR assays were carried out with a StepOne Plus real-time PCR instrument (Applied Biosystems, Waltham, MA, USA). qPCR reactions ( $20 \mu \mathrm{l})$ contained 1-18 ng of DNA, $400 \mathrm{nM}$ of each primer and $10 \mu \mathrm{l}$ of SensiFast SYBR HiROX kit (Bioline, Memphis, TN, USA). The qPCR reaction consisted of an initial denaturation step at $95{ }^{\circ} \mathrm{C}$ for 3 min, followed by 40 cycles of $95^{\circ} \mathrm{C}$ for $20 \mathrm{~s}, 60^{\circ} \mathrm{C}$ for $20 \mathrm{~s}$ and $72{ }^{\circ} \mathrm{C}$ for $30 \mathrm{~s}$. Data were acquired at $88^{\circ} \mathrm{C}$ for $15 \mathrm{~s}$ to avoid quantification of primer dimers. Agarose gel electrophoresis and melting curves obtained by increasing the temperature in $0.3^{\circ} \mathrm{C}$ increments from 60 to $95^{\circ} \mathrm{C}$ were used to determine specificity of qPCR reactions. iso $A$ gene copy numbers were determined from qPCR of ten-fold dilution series with DNA standards. Standards were prepared by cloning the isoA gene of Rhodococcus sp. AD45 into the pGEM ${ }^{\circledR} \mathrm{T}$ Easy vector (Promega, Madison, WI, USA) to be used as template DNA. The detection limit was $10^{2}$ copies per $20 \mu \mathrm{l}$ reaction. Efficiency of all qPCRs ranged from $96-104 \%$. iso $A$ copies were normalised to $16 \mathrm{~S}$ rRNA gene copy number (with the assumption of a rough ratio of 1:1 isoA to $16 \mathrm{~S}$ rRNA gene within a genome) in order to estimate the relative abundance of isoprene degrading bacteria in each environmental sample.

Number of copies of 16S rRNA genes was determined by qPCR using $519 \mathrm{~F}$ and $907 \mathrm{R}$ primers [75]. Reactions $(20 \mu \mathrm{l})$ contained $10-70 \mathrm{pg}$ DNA, $400 \mathrm{nM}$ of each primer and $10 \mu \mathrm{l}$ of SensiFast SYBR Hi-ROX kit. The qPCR reaction consisted of an initial denaturation step at $95^{\circ} \mathrm{C}$ for $3 \mathrm{~min}$, followed by 40 cycles of $95^{\circ} \mathrm{C}$ for $20 \mathrm{~s}, 55^{\circ} \mathrm{C}$ for $20 \mathrm{~s}$ and $72{ }^{\circ} \mathrm{C}$ for $30 \mathrm{~s}$. Data were collected at $72{ }^{\circ} \mathrm{C}$ for $15 \mathrm{~s}$. Specificity of the qPCR reaction and quantification of $16 \mathrm{~S}$ rRNA gene copy number were determined as described above.

\section{Results and discussion \\ Profiling the bacterial community associated with Salix fragilis leaves}

To identify the active isoprene degraders associated with willow leaves, a DNA SIP experiment was set up using ${ }^{13} \mathrm{C}$-labelled isoprene in microcosms consisting of cells washed from leaves incubated in minimal medium with a headspace of isoprene vapour (150 ppmv). DNA was extracted from cells following consumption of approximately $0.5 \mu \mathrm{mol}$ isoprene $\mathrm{ml}^{-1}$ (13-53 days). Density gradient ultracentrifugation and fractionation of DNA from samples incubated with ${ }^{12} \mathrm{C}$ or ${ }^{13} \mathrm{C}$ isoprene resulted 
in the recovery of light and heavy fractions from both sets of incubations, with heavy buoyant density samples from the ${ }^{13} \mathrm{C}$ incubations containing the enriched isoprene degrading community. The DNA extracted from these samples was analysed by $16 \mathrm{~S}$ rRNA gene amplicon sequencing and shotgun metagenomics.

Following denoising and removal of chimeric sequences, a total of 3,368 ASVs were obtained from $16 \mathrm{~S}$ rRNA amplicon sequence data across all samples and replicates. The average number of cleaned and processed reads used to collate ASVs was 561,187.

In those samples incubated with isoprene, although there was a variation between replicates (Fig. 1), unlabelled samples $\left({ }^{12} \mathrm{C}\right.$ light and heavy, and ${ }^{13} \mathrm{C}$ light) shared many similarities. The labelled, heavy fraction of ${ }^{13} \mathrm{C}$-incubated samples were clearly distinct from these controls, indicating that the enrichment of isoprene degrading bacteria was successful.

Unenriched T0 samples were consistent across all replicates and were dominated by Sphingomonas with an average relative abundance (RA) of $33.86 \pm 0.57 \%$. Other notable taxa present were Microbacteriaceae (RA of
$9.78 \pm 1.76 \%$ ), Hymenobacter (RA of $12.19 \pm 1.54 \%$ ) and Methylobacterium (RA of $5.09 \pm 0.26 \%$ ).

Control light fraction samples incubated with ${ }^{12} \mathrm{C}$ isoprene were quite distinct between replicates in terms of their bacterial diversity. Replicate 1 showed an abundance of Hydrocarboniphaga with an RA of $45.35 \%$ although the genus was not found in other replicates. Mycobacterium was found in replicates 1 and 2 with an RA of $6.94 \%$ and $13.32 \%$ respectively. Comamonadaceae was seen in all replicates with low RA in replicates 1 and 2 (RA of $3.39 \%$ and $1.75 \%$ respectively) but showed higher abundance in replicate 3, with an RA of $29.59 \%$. Caulobacter was present in all replicates with an average RA of $7.91 \pm 5.76 \%$.

In practice, it is expected that DNA would be recovered from all fractions during the fractionation process, but in the heavy fractions of ${ }^{12} \mathrm{C}$-incubated samples, the only driver for a change in diversity would be caused by a particularly high GC content in a given taxa, this is the reason why such a low proportion of DNA is recovered from these samples ( $1 \%$ in this study). Outside of this occurrence, the heavy and light fractions of ${ }^{12} \mathrm{C}$-incubated

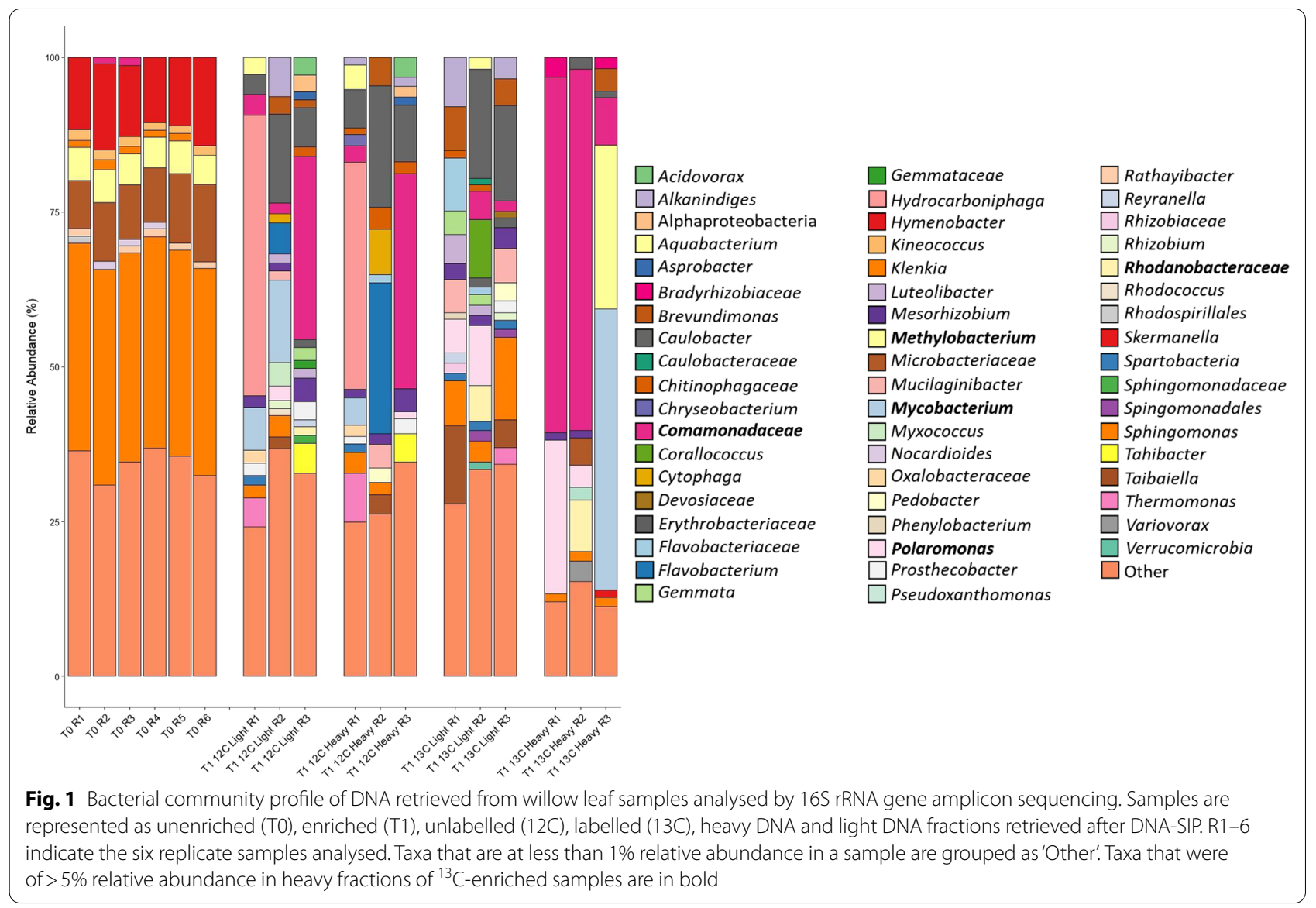


samples were expected to be very similar, as can be seen in Fig. 1.

The light DNA fractions of samples incubated with isotopically labelled ${ }^{13} \mathrm{C}$ isoprene contained the Caulobacter also seen in samples incubated with ${ }^{12} \mathrm{C}$, with an RA of $17.58 \%$ and $15.40 \%$ in replicates 2 and 3 . Other than this, the light fractions of samples incubated with ${ }^{13} \mathrm{C}$ do show some clear differences. Sphingomonas were present across all replicates with an average RA of $7.99 \pm 5.06 \%$, the presence of Tabiella in replicates 1 and 3 was also unique to this group of samples, with an RA of $12.69 \%$ and $4.46 \%$ respectively (Fig. 1 ).

Finally, the heavy fraction of samples incubated with ${ }^{13} \mathrm{C}$ isoprene represent those bacteria that utilised the labelled isoprene during the process of reproduction and growth, confirming that these bacteria have the metabolic capacity to assimilate carbon from isoprene. The distinctive bacterial community seen in these samples indicates that the selective pressure introduced by the DNA SIP experiment was successful in enriching these bacterial taxa. A substantial increase in the relative abundance of Comamonadaceae was seen in replicates 1 and 2, with an RA of $57.48 \%$ and $58.33 \%$ respectively. Polaromonas was also enriched with an RA of $24.78 \%$ in replicate 1 , although this was not present in the other two replicates. A very notable shift in the bacterial community was seen with replicate 3 . Here the abundance of Comamonadaceae was not observed, and instead, there was a higher abundance of Methylobacterium (RA of 26.48\%) which was not seen in any of the other enriched fractions or samples. However, as mentioned earlier, it was present in unenriched T0 samples (RA of $5.09 \pm 0.26 \%$ ). A substantial increase in abundance of Mycobacterium with an RA of $45.39 \%$ was also observed (Fig. 1).

Further analysis of the bacterial community structure was undertaken by examining metagenomic data obtained after DNA-SIP incubations as described in Materials and Methods. These data were analysed and taxonomically classified using Kraken [62] and revealed the presence of a number of genera belonging to the family Comamonadaceae, with Acidovorax (RA of $14 \%$ ), Variovorax (RA of $10.83 \%$ ), Polaromonas (RA of $3.8 \%$ ), Hydrogenophaga (RA of $3.2 \%$ ), Ramlibacter (RA of $2.7 \%$ ) and Rhodoferax (RA of $2.5 \%$ ) being recovered in ${ }^{13} \mathrm{C}$-labelled, heavy DNA (Fig. 2). The presence of a number of different genera of the Comamonadacea in this phyllosphere environment mirrors a previous study which focused on the bacterial community of soil associated with a willow species where Comamonadaceae made up $21-30 \%$ of the relative abundance in ${ }^{13} \mathrm{C}$-incubated heavy samples [42]. Although the two environments are different, this shared abundance might suggest members of the phyllosphere community are being transported

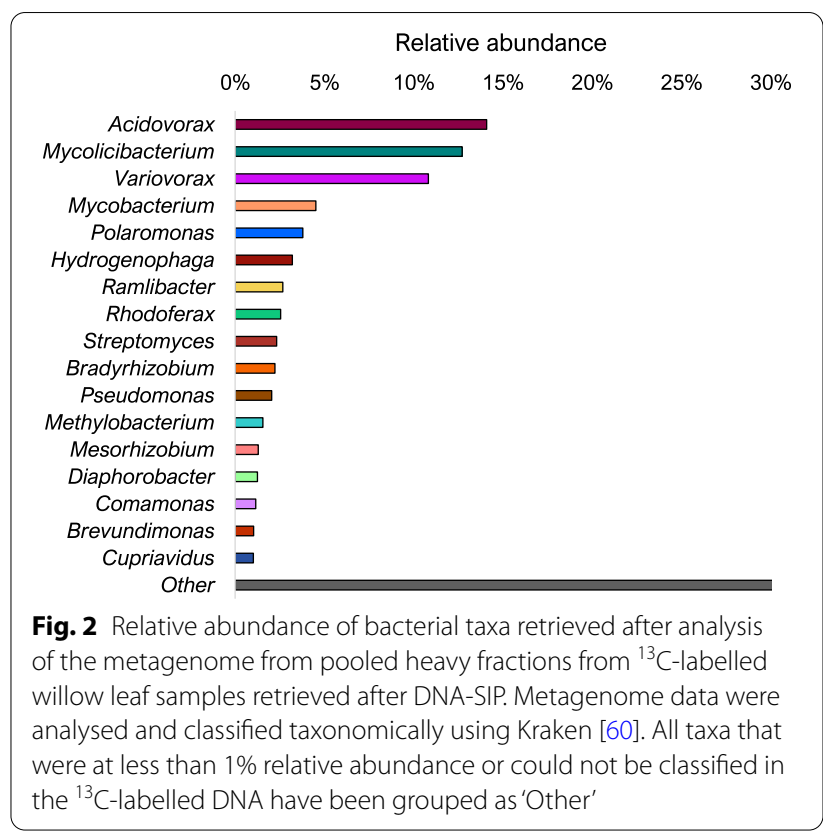

to the bulk soil environment, possibly though rainfall or falling leaves.

Bradyrhizobium from the order Rhizobiales which was observed after 16S rRNA gene amplicon analysis (Fig. 1) was also observed after metagenome analyses with an RA of $2.23 \%$ (Fig. 2). Mycolicibacterium had been labelled with an RA of $12.72 \%$. This genus, which has recently been differentiated from the genus Mycobacterium [76], was also found in the heavy DNA fractions arising from ${ }^{13} \mathrm{C}$-labelled SIP incubations after $16 \mathrm{~S}$ rRNA gene amplicon analysis (Fig. 1). Mycobacterium itself made up $4.52 \%$ of the metagenomic community. Previously, iso $A$ sequences sharing high sequence similarity with the iso $A$ of Mycobacterium AT1 were estimated to make up half of all iso $A$ sequences present on the leaves of sampled willow leaves [48]. However, this is the first instance of Mycobacterium being significantly enriched in ${ }^{13} \mathrm{C}$-incubated heavy fractions from a DNA SIP experiment with terrestrial samples.

Methylobacterium, which was estimated to be present at high relative abundance in $16 \mathrm{~S}$ rRNA gene amplicon analysis of the heavy DNA fraction from ${ }^{13} \mathrm{C}$ isopreneincubated replicate 3 , also featured in the metagenome analysis with an RA of $1.5 \%$. The appearance of a ${ }^{13} \mathrm{C}$-labelled Methylobacterium here is interesting, since Methylobacterium species have previously been reported to grow on isoprene $[77,78]$ but are still quite rare in studies examining isoprene-degrading communities in the environment.

Without an extant example of the strains that make up the Methylobacterium ASVs, it cannot be said with 
absolute certainty that they do have the metabolic capability to degrade isoprene, but their presence in the heavy fraction of ${ }^{13} \mathrm{C}$ isoprene-enriched samples (while not abundant in the heavy ${ }^{12} \mathrm{C}$ controls) suggests they have indeed utilised the ${ }^{13} \mathrm{C}$-labelled isoprene during growth. However, there is the possibility that labelled by-products of isoprene metabolism produced by other organisms in the microcosm during isoprene degradation could have been assimilated by Methylobacterium. As the only methylotroph linked to isoprene degradation, further analysis confirming Methylobacterium to be an isoprene-degrading bacterium would be of great interest.
Analysis of an abundant Mycobacteriaceae MAG containing two isoprene monooxygenase gene clusters

Contigs obtained from metagenomic data were binned and a number of metagenome assembled genomes (MAGs) were recovered (Table 1). Of these MAGs, one identified as belonging to the family Mycobacteriaceae, was selected for further investigation due to the presence of a complete isoprene (iso) metabolic gene cluster. This MAG was the most abundant of those recovered with 325 genome copies per million reads. On further investigation using the MiGA pipeline [74], the MAG was identified to genus level as Mycobacterium.

Table 1 Statistics for the completeness and abundance of recovered MAGs

\begin{tabular}{|c|c|c|c|c|c|}
\hline Abundance Ranking & Completeness (\%) & Contamination (\%) & N50 & Size (Mbp) & ID \\
\hline $1 s t$ & 99.62 & 1.31 & 426,339 & 7.4 & Mycobacteriaceae \\
\hline 2nd & 84.53 & 2.30 & 28,949 & 4 & Comamonadaceae \\
\hline $3 r d$ & 78.65 & 1.48 & 19,712 & 3.4 & Comamonadaceae \\
\hline 4 th & 71.3 & 1.52 & 21,622 & 5 & Comamonadaceae \\
\hline 5 th & 92.4 & 1.12 & 70,582 & 4.4 & Comamonadaceae \\
\hline 6 th & 92.75 & 4.48 & 56,291 & 6.1 & Comamonadaceae \\
\hline 7 th & 89.21 & 2.45 & 47,756 & 4 & Comamonadaceae \\
\hline 8th & 88.71 & 2.81 & 33,346 & 4.3 & Comamonadaceae \\
\hline 9th & 98.86 & 0.17 & 91,899 & 4.8 & Methylobacteriaceae \\
\hline 10th & 89.89 & 5.65 & 114,304 & 8.7 & Myxococcales \\
\hline 11 th & 92.9 & 5.46 & 59,280 & 4.8 & Comamonadaceae \\
\hline 12th & 94.35 & 1.02 & 64,831 & 3.9 & Burkholderiales \\
\hline 13th & 98.77 & 0.80 & 142,624 & 4.2 & Xanthomonadaceae \\
\hline 14 th & 77.75 & 8.04 & 36,155 & 3.9 & Comamonadaceae \\
\hline 15 th & 98.98 & 0.76 & 201,989 & 3.3 & Microbacteriaceae \\
\hline 16th & 98.77 & 1.31 & 170,797 & 3.8 & Sphingomonadaceae \\
\hline 17 th & 90.67 & 3.08 & 28,589 & 5.7 & Burkholderiales \\
\hline 18th & 87.71 & 0.53 & 197,524 & 2.8 & Caulobacteraceae \\
\hline 19th & 97.15 & 7.72 & 93,325 & 4.1 & Caulobacteraceae \\
\hline 20th & 95.4 & 1.74 & 263,888 & 4.2 & Bradyrhizobiaceae \\
\hline $21 s t$ & 91.19 & 13.04 & 33,095 & 3.2 & Caulobacteraceae \\
\hline 22nd & 96.75 & 1.15 & 93,753 & 3.4 & Xanthomonadaceae \\
\hline $23 r d$ & 96.77 & 2.96 & 58,108 & 8.5 & Proteobacteria \\
\hline 24 th & 93.05 & 2.47 & 50,463 & 8.2 & NA \\
\hline 25th & 88.3 & 3.19 & 14,127 & 3.5 & Alphaproteobacteria \\
\hline 26th & 88.11 & 0.93 & 49,319 & 3.8 & NA \\
\hline 27 th & 91.77 & 0.69 & 14,215 & 3.3 & Nocardioidaceae \\
\hline 28th & 91.73 & 3.23 & 29,968 & 3.1 & Xanthomonadaceae \\
\hline 29th & 91.33 & 1.21 & 15,927 & 5.7 & Mycobacteriaceae \\
\hline 30th & 82.26 & 9.74 & 5,017 & 4.4 & Bradyrhizobiaceae \\
\hline $31 s t$ & 74.49 & 1.32 & 5,029 & 3.2 & Xanthomonadaceae \\
\hline $32 n d$ & 73.68 & 1.85 & 3,730 & 2.5 & Alphaproteobacteria \\
\hline $33 \mathrm{rd}$ & 80.6 & 0.49 & 6,496 & 4.5 & Bacteroidetes \\
\hline 34th & 81.82 & 1.21 & 3,958 & 3.3 & Sphingobacteriaceae \\
\hline
\end{tabular}


The Mycobacterium MAG has two non-identical copies of the iso gene cluster isoABCDEFGHIJ (referred to as iso cluster 1 and iso cluster 2), encoding enzymes of the isoprene degradation pathway (reviewed in [41, 43]), together with associated genes aldH1, CoA-DSR, gshB and $\operatorname{mar} R$, encoding an aldehyde dehydrogenase, a CoAdisulfide reductase, a glutathione synthase and a putative transcriptional regulator respectively (Fig. 3A, B).

To rule out the possibility that one of these duplicate clusters was an artefact of assembly or contamination, the contigs containing both clusters were investigated for the presence of essential marker genes, and each marker gene was analysed for possible duplication. Both contigs were of substantial length (995,005 bp and 363,049 bp) with coverage $>400 \times$, and contained single copies of marker genes consistent with the genome of a member of the Mycobacteriaceae, which strongly suggested that there was no contamination and that this MAG did indeed contain two iso gene clusters. This Mycobacterium MAG was also investigated for genes that would indicate the presence of a plasmid but none were found, suggesting that both iso gene clusters are located on the genome and are not plasmid-borne as found in Rhodococcus strain AD45 and Variovorax strain WS11 [37, 79], two isoprene degrading strains that contain duplicated genes within a single isoprene degradation cluster, but do not contain duplicate copies of the full iso gene cluster.

The translated polypeptide sequences of iso genes from both clusters showed a high degree of identity $(>75 \%$ amino acid identity) to the corresponding polypeptides found in the isoprene-degrading Mycobacterium AT1 [36], although Mycobacterium AT1 also contained only one copy of the iso metabolic gene cluster (Additional file 1: Table S1).

\section{Identification of a propane monooxygenase gene cluster in Mycobacterium}

The genome of the recovered Mycobacterium MAG was investigated for other metabolic genes of interest and a full propane monooxygenase gene cluster was

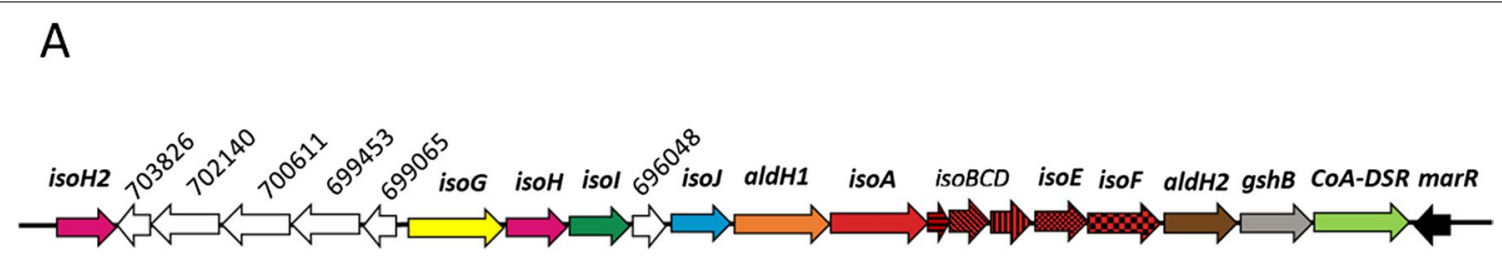

B
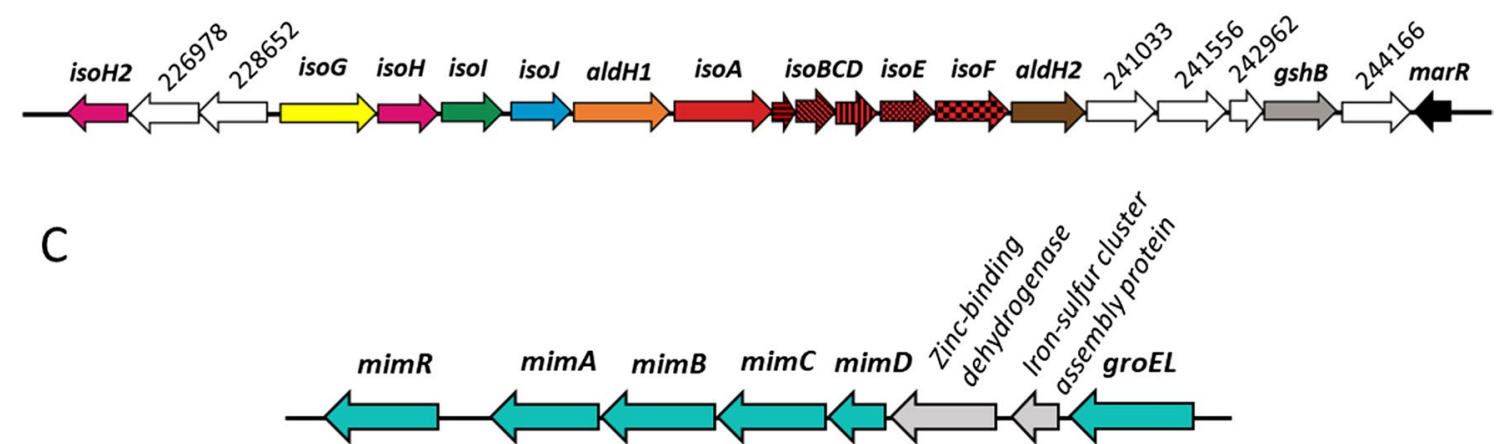

Fig. 3 Isoprene degradation gene clusters recovered from MAGs assembled from heavy DNA incubated with ${ }^{13} \mathrm{C}$ isoprene. A, B iso clusters 1 and 2 recovered from a Mycobacterium MAG assembled from heavy DNA retrieved after DNA-SIP. Genes encoding IsoMO (isoABCDEF) are coloured in red. Adjacent genes isoGHIJ and the duplicate gene isoH2 encode a CoA transferase, dehydrogenase and two glutathione transferases involved in the subsequent steps of isoprene metabolism. Genes aldH1, COA-DSR, gshB and marR encode an aldehyde dehydrogenase, a CoA-disulfide reductase, a glutathione synthase and a putative transcriptional regulator respectively. Adjacent genes that are not yet known to be involved in isoprene degradation are coloured in white. (696 048-Hypothetical protein; 699 065-Hypothetical protein; 699 453-Hypothetical protein; 700611 - Triacylglycerol lipase; 702 140_Acetyl-CoA-acetyltransferase; 703 826_AraC family transcriptional regulator; 226 978Acetyl-CoA-acetyltransferase; 228 652-Hypothetical protein; 241033 - Hypothetical protein; 241 556-Hypothetical protein; 242 962-CaiB/ BaiF family protein; 244 166_FAD-dependant oxidoreductase). Regulatory genes are shown in black. C A propane monooxygenase gene cluster recovered from a Mycobacterium MAG. Genes associated with propane metabolism are coloured in blue. Genes mimABCD encode an oxygenase large subunit, a reductase, an oxygenase small unit and a coupling protein respectively, making up the propane monooxygenase, with groEL encoding an associated chaperonin $[75,76]$. Adjacent genes not involved in propane metabolism are coloured in grey 
recovered which comprised of genes $\operatorname{mim} A B C D$ and the propane monooxygenase operon transcriptional regulator $\operatorname{mimR}$, along with the associated chaperonin groEL (Fig. 3C) [80]. The propane monooxygenase is a binuclear iron monooxygenase encoded by genes mim $A B C D$ that encode an oxygenase large subunit, a reductase, an oxygenase small unit and a coupling protein respectively. Such gene clusters share high amino acid identity to the propane monooxygenase encoded by the prmABCD gene clusters found in Rhodococcus sp. strain RHA1 [81] and Gordonia sp. strain TY-5 [82]. The propane monooxygenase in these bacteria is essential for propane and acetone metabolism and is capable of oxidizing phenol to hydroquinone in the presence of acetone [83]. However, the propane monooxygenase found in Mycobacterium AT1 did not allow growth on phenol [36].

The recovered MimABCDR polypeptides all shared a high amino acid identity (>97\%) with the corresponding polypeptides found in Mycobacterium AT1 (Additional file 1: Table S2), a bacterium that could grow on propane and ethane $[36,84]$. However, amino acid identity (AAI) analysis of the genome as a whole gave a shared identity of $92.09 \%$, indicating that although they are closely related, they are not the same species (same species share an AAI of $95 \%$ or above). Additional file 1: Table S2 also shows comparison of Mim polypeptides to the wellcharacterised Mycobacterium smegmatis strain $\mathrm{mc}^{2} 155$ in which, alongside propane and acetone metabolism, mim $A B C D$ encode enzymes responsible for the regioselective oxidation of phenol to hydroquinone, similar to those of Rhodococcus sp. strain RHA1 and the Gordonia sp. strain TY-5 mentioned earlier [80, 83].

\section{Recovery of a Methylobacterium MAG, present in the isoprene-degrading community as revealed by DNA-SIP}

Another MAG, identified as Methylobacteriaceae, showed high (98.86\%) completion and low $(0.17 \%)$ contamination (Table 1). It was also one of the most abundant MAGs recovered from metagenome data, following Comamonadaceae and Mycobacterium, with 49 genome copies per million reads. Methylobacterium, a member of the Methylobacteriaceae family, were found to be notably enriched in the heavy fraction of one of the ${ }^{13} \mathrm{C}$-incubated samples in $16 \mathrm{~S}$ rRNA analysis (Fig. 1), however this MAG contained no iso genes or obvious alternatives that might provide the microbe with the metabolic ability to degrade isoprene.

Further analysis recovered a full $m x a$ methylotrophy gene cluster encoding a calcium-containing methanol dehydrogenase (mxaFJGIRSACKLDEHB) with an upstream mxaW, a methanol regulated gene of unknown function $[85,86]$. In addition, six genes required for pyrroloquinoline quinone (PQQ) synthesis were found, $(p q q A B C / D E)$ and (pqqFG)[86]. Genes $m x b D M$ and $m x c Q E$ involved in transcriptional regulation of the methanol oxidation system were also present. Comparison between these genes and the same clusters from the well characterised Methylobacterium extorquens AM1 can be seen in Additional file 1: Table S3 [87].

\section{Abundance of bacteria associated with the leaves of willow and other plant species encoding for the isoprene monooxygenase alpha-subunit}

The DNA-SIP experiments described earlier enabled the identification of active isoprene-degrading bacteria on the surface of willow leaves. Analysis of MAGs retrieved from heavy DNA after DNA-SIP experiments also confirmed that isoprene-degraders present contained iso metabolic gene clusters with significant identity to those of well-characterised isoprene-degraders and that iso $A$, encoding the putative active site of IsoMO was again highly conserved in these MAGs. In order to gain initial insights into the relative abundance of isoprene degraders on willow leaves and to compare with other tree species, the abundance of $i s o A$-containing bacteria associated with leaves of the willow bioenergy crop Salix viminalis, was investigated with the use of qPCR following methods described previously [48]. For comparison, the leaves of the high isoprene-producing crop Poplar nigra and the non-producer Miscanthus x giganteus were also analysed. Results showed that the willow leaves sampled harboured an average of $1379 \pm 1030$ isoA sequences per million copies of $16 \mathrm{~S}$ rRNA genes, indicating an average of $\sim 0.14 \%$. In comparison, leaves of the high isoprene-emitting poplar species contained $1473 \pm 911$ iso $A$ sequences per million $16 \mathrm{~S}$ rRNA genes, equating to approximately $0.15 \%$. The non-emitting Miscanthus species showed $801 \pm 704$ iso $A$ sequences per million $16 \mathrm{~S}$ rRNA genes, representing about $0.07 \%$ (Fig. 4). While the average number of $16 \mathrm{~S}$ rRNA genes per species can vary widely between taxa and it cannot be assumed that iso $A$ genes are present in bacterial genomes in a 1:1 ratio with $16 \mathrm{~S}$ rRNA genes, this metric can only act as an approximation of the abundance of isoprene degrading bacteria in the wider bacterial community. As such, these results demonstrate a much higher abundance of isoA-containing bacteria in isoprene-rich leaf environments compared to leaves of a plant that does not emit isoprene. However, in comparisons between species that emit isoprene, there does not appear to be a linear correlation between isoprene production and number of isoprene degrading bacteria. It has been reported that Populus nigra emits 29-76 $\mu \mathrm{g} \mathrm{g}^{-1}$ (dry weight) $\mathrm{h}^{-1}$ of isoprene, while Salix viminalis emits $80-130 \mu \mathrm{g} \mathrm{g}^{-1}$ (dry weight) $\mathrm{h}^{-1}[49,88-$ 90]. Estimated numbers of potential isoprene degrading 


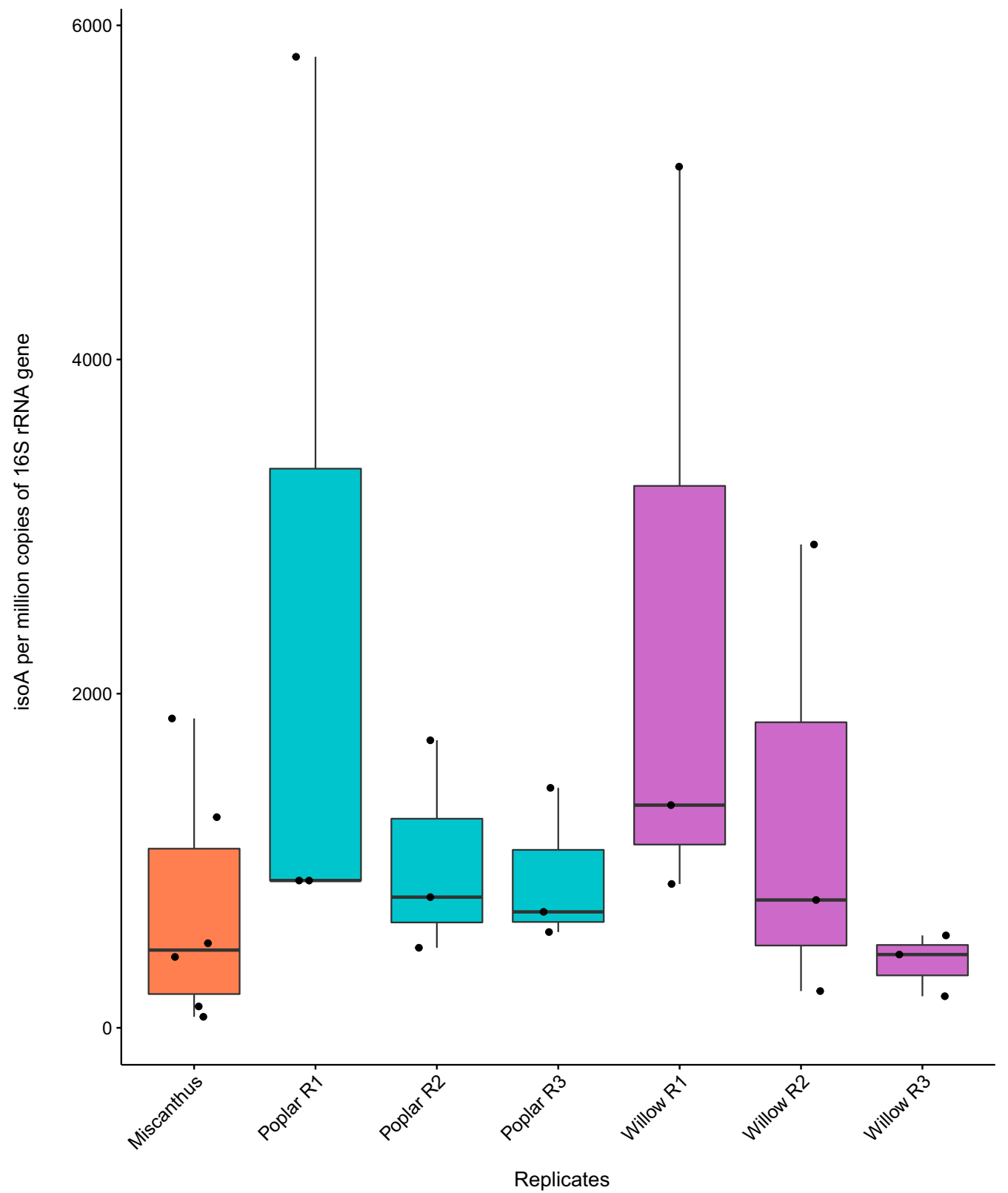

Fig. 4 Relative abundance of isoprene degraders in DNA retrieved from samples of leaf washings from Miscanthus, poplar and willow trees. Samples were analysed by qPCR of isOA genes (48). isoA copies were normalised to the number of 16S rRNA gene copies present in each DNA sample. The three replicates for poplar and willow samples represent individual trees, while data points within replicates each represent $2 \mathrm{~g}$ of leaves taken from around each tree. Data points with samples from Miscanthus each represent a single grass leaf

bacteria found in willow samples however were marginally lower than those in poplar samples. This preliminary examination of the abundance of $i s o A$ sequences associated with isoprene-degrading trees confirms at least their presence and relatively high abundance when compared to a non-isoprene producing crop plant (Miscanthus).
However, these data need to be interpreted with caution since the qPCR data were highly variable between plants and this may have been due to the ease (or otherwise) with which bacteria can be removed from different types of leaves. Our DNA-SIP study and isoA assays provide proof-of principle for the study of isoprene cycling in the 
environment and clearly show that isoprene-degrading bacteria are present in significant numbers in these environments but in future, a more systematic, quantitative study of isoprene-degrading bacteria, comparing a wide variety of high- and low-isoprene emitting trees, will be required. This could include analysis of transcripts to look more closely at the difference in isoprene degrading activity between such species.

\section{Conclusions}

Focussed metagenomics using DNA-SIP with ${ }^{13} \mathrm{C}$-labelled isoprene and leaf washings from a high isoprene-emitting willow tree enabled identification of active isoprene-degrading bacteria from this environment. Active isoprene-degraders included various members of the Comamonadaceae family and the Actinobacteria phylum. Analysis of metagenome sequence data from heavy DNA retrieved after SIP experiments enabled the assembly of a MAG from a putative-isoprene degrading Mycobacterium which contained at least two soluble diiron-containing monooxygenase gene clusters; duplicate copies of the iso metabolic cluster (isoABCDEF$G H I)$, together with a putative propane monooxygenase gene cluster (mimABCD). Also of particular interest was a putative isoprene degrading Methylobacterium which warrants further study. These cultivation-independent approaches provide DNA sequence data to assist targeted isolation of isoprene degrading bacteria from the phyllosphere and provide proof-of-concept for more detailed quantitative studies on isoprene-degraders present on the leaves of high-isoprene-emitting trees.

\section{Supplementary Information}

The online version contains supplementary material available at https://doi. org/10.1186/s40793-021-00386-x.

Additional file 1: Table S1. Comparison of polypeptides recovered from the duplicate isoprene degradation gene clusters (iso cluster 1 and iso cluster 2; Figure 3) found in a Mycobacterium MAG to those recovered from Mycobacterium AT1 and the well-characterised Rhodococcus AD45. Table S2. Comparison of polypeptides recovered from a propane monooxygenase gene cluster recovered from a Mycobacterium MAG to those recovered from Mycobacterium AT1 and the well-characterised Mycobacterium smegmatis $m^{c} 2155$. Table S3. Comparison of polypeptides associated with the oxidation of methanol to formaldehyde recovered from a Methylobacteriaceae MAG, compared to the well characterised Methylobacterium extorquens AM1. Fig. S1. Percentage of DNA retrieved as a function of the density of each fraction following density gradient ultracentrifugation.

\section{Acknowledgements}

Not applicable.

\section{Authors' contributions}

ATC, LG and JCM planned the experiments. ATC and LG carried out the experimental work. LG undertook the analysis of results. LG, ATC and NPMCN collected and processed samples. LG and ATC wrote the manuscript with contributions from all authors. All authors read and approved the manuscript before submission.

\section{Funding}

The work on this project was funded through a European Research Council Advanced Grant to JCM (694578-IsoMet), a Natural Environment Research Council grant (NE/J009725/1) and the Earth and Life Systems Alliance (ELSA) at the University of East Anglia. Work in NPMCN laboratory was funded by the UK Natural Environment Research Council (SUNRISE Project; NE/R000131/1).

\section{Availability of data and materials}

Amplicon sequencing and metagenomic reads are available from the sequence read archive (SRA) under Bioproject PRJNA272922 (amplicon Biosamples SAMN18058298 - SAMN18058333, metagenomic Biosamples SAMN18095267-SAMN18095269).

\section{Declarations}

Ethics approval and consent to participate

Not applicable.

\section{Consent for publication}

Not applicable.

\section{Competing interests}

The authors declare that they have no competing interests.

\section{Author details}

${ }^{1}$ School of Environmental Sciences, University of East Anglia, Norwich Research Park, Norwich NR4 7TJ, UK. ${ }^{2}$ School of Biological Sciences, University of East Anglia, Norwich Research Park, Norwich NR4 7TJ, UK. ${ }^{3}$ Centre of Ecology and Hydrology, Lancaster University, Bailrigg, Lancaster LA1 4AP, UK.

Received: 13 April 2021 Accepted: 12 August 2021

Published online: 26 August 2021

\section{References}

1. Atkinson R, Arey J. Gas-phase tropospheric chemistry of biogenic volatile organic compounds: a review. Atmos Environ. 2003;37:197-219.

2. Guenther $A B$, Jiang $X$, Heald $C L$, Sakulyanontvittaya T, Duhl T, Emmons LK, et al. The model of emissions of gases and aerosols from nature version 2.1 (MEGAN2.1): An extended and updated framework for modeling biogenic emissions. Geosci Model Dev. 2012;5:1471-92.

3. Sanderson MG, Jones CD, Collins WJ, Johnson CE, Derwent RG. Effect of climate change on isoprene emissions and surface ozone levels. Geophys Res Lett. 2003;30(18). https://doi.org/10.1029/2003GL017642.

4. Monson RK, Trahan N, Rosenstiel TN, Veres P, Moore D, Wilkinson M, et al. Isoprene emission from terrestrial ecosystems in response to global change: minding the gap between models and observations. Philos Trans R Soc A Math Phys Eng Sci. 2007;365:1677-95.

5. Engelhart GJ, Moore RH, Nenes A, Pandis SN. Cloud condensation nuclei activity of isoprene secondary organic aerosol. J Geophys Res. 2011;116:D02207.

6. Morais ARC, Dworakowska S, Reis A, Gouveia L, Matos CT, Bogdał D, et al. Chemical and biological-based isoprene production: Green metrics. Catal Today. 2015;239:38-43.

7. Kuzma J, Nemecek-Marshall M, Pollock WH, Fall R. Bacteria produce the volatile hydrocarbon isoprene. Curr Microbiol. 1995;30:97-103.

8. Fall R, Copley SD. Bacterial sources and sinks of isoprene, a reactive atmospheric hydrocarbon. Environ Microbiol. 2000;2:123-30.

9. Bäck J, Aaltonen H, Hellén H, Kajos MK, Patokoski J, Taipale R, et al. Variable emissions of microbial volatile organic compounds (MVOCs) from root-associated fungi isolated from Scots pine. Atmos Environ. 2010;44:3651-9.

10. Shaw SL, Gantt B, Meskhidze N. Production and emissions of marine isoprene and monoterpenes: a review. Adv Meteorol. 2010;1-24. 
11. Exton DA, Suggett DJ, McGenity TJ, Steinke M. Chlorophyll-normalized isoprene production in laboratory cultures of marine microalgae and implications for global models. Limnol Oceanogr. 2013;58:1301-11.

12. Srikanta Dani KGG, Silva Benavides AM, Michelozzi M, Peluso G, Torzillo G, Loreto F. Relationship between isoprene emission and photosynthesis in diatoms, and its implications for global marine isoprene estimates. Mar Chem. 2017;189:17-24

13. Crombie AT, Mejia-Florez NL, McGenity TJ, Murrell JC. Genetics and ecology of isoprene degradation. In: Aerobic utilization of hydrocarbons, oils and lipids. Cham: Springer; 2017. pp. 1-15.

14. Steinke M, Hodapp B, Subhan R, Bell TG, Martin-Creuzburg D. Flux of the biogenic volatiles isoprene and dimethyl sulfide from an oligotrophic lake. Sci Rep. 2018:8:1-10.

15. Geron C, Owen S, Guenther A, Greenberg J, Rasmussen R, Hui Bai J, et al. Volatile organic compounds from vegetation in southern Yunnan Province, China: emission rates and some potential regional implications. Atmos Environ. 2006:40:1759-73.

16. Loreto F, Ciccioli P, Brancaleoni E, Valentini R, De Lillis M, Csiky O, et al. A hypothesis on the evolution of isoprenoid emission by oaks based on the correlation between emission type and Quercus taxonomy. Oecologia. 1998;115:302-5.

17. Logan BA, Monson RK, Potosnak MJ. Biochemistry and physiology of foliar isoprene production. Trends Plant Sci. 2000;5:477-81.

18. Monson RK, Jones RT, Rosenstiel TN, Schnitzler JP. Why only some plants emit isoprene. Plant Cell Environ. 2013;36:503-16.

19. Sharkey TD. Is it useful to ask why plants emit isoprene? Plant Cell Environ. 2013;36:517-20.

20. Rohmer M. The discovery of a mevalonate-independent pathway for isoprenoid biosynthesis in bacteria, algae and higher plants. Nat Prod Rep. 1999;16:565-74.

21. Monson RK, Fall R. Isoprene emission from aspen leaves : influence of environment and relation to photosynthesis and photorespiration. Plant Physiol. 1989;90:267-74.

22. Sharkey TD, Yeh S. Isoprene emission from plants. Annu Rev Plant Physiol Plant Mol Biol. 2001;52:407-36.

23. Behnke $K$, Ehlting B, Teuber M, Bauerfeind M, Louis S, Hänsch R, et al. Transgenic, non-isoprene emitting poplars don't like it hot. Plant J. 2007:51:485-99.

24. Laothawornkitkul J, Paul ND, Vickers CE, Possell M, Taylor JE, Mullineaux PM, et al. Isoprene emissions influence herbivore feeding decisions. Plant Cell Environ. 2008;31:1410-5.

25. Vickers CE, Possell M, Cojocariu Cl, Velikova VB, Laothawornkitkul J, Ryan A, et al. Isoprene synthesis protects transgenic tobacco plants from oxidative stress. Plant Cell Environ. 2009:32:520-31.

26. Sharkey TD, Wiberley AE, Donohue AR. Isoprene emission from plants: why and how. Ann Bot. 2007;101:5-18.

27. Velikova V, Sharkey TD, Loreto F. Stabilization of thylakoid membranes in isoprene-emitting plants reduces formation of reactive oxygen species. Plant Signal Behav. 2012;7:139-41.

28. Harvey CM, Li Z, Tjellström H, Blanchard GJ, Sharkey TD. Concentration of isoprene in artificial and thylakoid membranes. J Bioenergy Biomembr. 2015;47:419-29.

29. Lantz AT, Allman J, Weraduwage SM, Sharkey TD. Isoprene: new insights into the control of emission and mediation of stress tolerance by gene expression. Plant Cell Environ. 2019;42:2808-26.

30. Cleveland CC, Yavitt JB. Consumption of atmospheric isoprene in soil. Geophys Res Lett. 1997;24:2379-82.

31. Cleveland CC, Yavitt JB. Microbial consumption of atmospheric isoprene in a temperate forest soil. Appl Environ Microbiol. 1998;64:172-7.

32. Gray CM, Helmig D, Fierer N. Bacteria and fungi associated with isoprene consumption in soil. Elem Sci Anthr. 2015;3:000053.

33. van Hylckama Vlieg JE, Kingma J, van den Wijngaard AJ, Janssen DB. A glutathione S-transferase with activity towards cis-1, 2-dichloroepoxyethane is involved in isoprene utilization by Rhodococcus sp. strain AD45. Appl Environ Microbiol. 1998;64:2800-5.

34. van Hylckama Vlieg JE, Kingma J, Kruizinga W, Janssen DB. Purification of a glutathione S-transferase and a glutathione conjugate-specific dehydrogenase involved in isoprene metabolism in Rhodococcus sp. strain AD45. J Bacteriol. 1999;181:2094-101.
35. Alvarez LA, Exton DA, Timmis KN, Suggett DJ, McGenity TJ. Characterization of marine isoprene-degrading communities. Environ Microbiol. 2009:11:3280-91.

36. Johnston A, Crombie AT, El Khawand M, Sims L, Whited GM, McGenity TJ, et al. Identification and characterisation of isoprene-degrading bacteria in an estuarine environment. Environ Microbiol. 2017;19:3526-37.

37. Crombie AT, El KM, Rhodius VA, Fengler KA, Miller MC, Whited GM, et al. Regulation of plasmid-encoded isoprene metabolism in Rhodococcus, a representative of an important link in the global isoprene cycle. Environ Microbiol. 2015;17:3314-29.

38. Crombie AT, Emery H, McGenity TJ, Murrell JC. Draft genome sequences of three terrestrial isoprene-degrading Rhodococcus strains. Genome Announc. 2017;5:e01256-e1317.

39. El Khawand M, Crombie AT, Johnston A, Vavlline DV, McAuliffe JC, Latone $J A$, et al. Isolation of isoprene degrading bacteria from soils, development of isoA gene probes and identification of the active isoprene-degrading soil community using DNA-stable isotope probing. Environ Microbiol. 2016:18:2743-53.

40. Crombie AT, Larke-Mejia NL, Emery H, Dawson R, Pratscher J, Murphy GP, et al. Poplar phyllosphere harbors disparate isoprene-degrading bacteria. Proc Natl Acad Sci U S A. 2018;115:13081-6.

41. McGenity TJ, Crombie AT, Murrell JC. Microbial cycling of isoprene, the most abundantly produced biological volatile organic compound on Earth. ISME J. 2018;12:931-41.

42. Larke-Mejia NL, Crombie A, Pratscher J, McGenity TJ, Murrell C. Novel isoprene-degrading Proteobacteria from soil and leaves identified by cultivation and metagenomics analysis of stable isotope probing experiments. Front Microbiol. 2019;10:2700.

43. Murrell JC, McGenity TJ, Crombie AT. Microbial metabolism of isoprene: a much-neglected climate-active gas. Microbiology (United Kingdom). 2020;166:600-13. https://doi.org/10.1099/mic.0.000931.

44. Carrión O, McGenity TJ, Murrell JC. Molecular ecology of isoprenedegrading bacteria. Microorganisms. 2020;8:967.

45. Dumont MG, Murrell JC. Innovation: stable isotope probing-linking microbial identity to function. Nat Rev Microbiol. 2005:3:499-504.

46. Neufeld JD, Vohra J, Dumont MG, Lueders T, Manefield M, Friedrich MW, et al. DNA stable-isotope probing. Nat Protoc. 2007;2:860-6.

47. Carrión O, Gibson L, Elias DMO, McNamara NP, Van Alen TA, Op Den Camp HJM, et al. Diversity of isoprene-degrading bacteria in phyllosphere and soil communities from a high isoprene-emitting environment: a Malaysian oil palm plantation. Microbiome. 2020;8:1-13.

48. Carrión O, Larke-Mejía NL, Gibson L, Farhan UI Haque M, Ramiro-García J, McGenity TJ, et al. Gene probing reveals the widespread distribution, diversity and abundance of isoprene-degrading bacteria in the environment. Microbiome. 2018;6:219.

49. Pio CA, Nunes TV, Brito S. Volatile hydrocarbon emissions from common and native species of vegetation in Portugal. In: Slanina J, Angeletti G, Beilke S, editors. Proceedings of the joint Workshop of CEC/BIATEX of EUROTRAC, General assessment of biogenic emissions and deposition of nitrogen compounds, sulfur compounds and oxidants in Europe. Air Pollution Research Report, Vol 47. 1993. p. 291-298.

50. Anstead L, Boar RR. Willow spiling: review of streambank stabilisation projects in the UK. Freshw Rev. 2010;3:33-47.

51. Aylott MJ, Casella E, Tubby I, Street NR, Smith P, Taylor G. Yield and spatial supply of bioenergy poplar and willow short-rotation coppice in the UK. New Phytol. 2008;178:358-70.

52. Drewer J, Finch JW, Lloyd CR, Baggs EM, Skiba U. How do soil emissions of $\mathrm{N}_{2} \mathrm{O}, \mathrm{CH}_{4}$ and $\mathrm{CO}_{2}$ from perennial bioenergy crops differ from arable annual crops? GCB Bioenergy. 2012;4:408-19.

53. Morrison EC, Drewer J, Heal MR. A comparison of isoprene and monoterpene emission rates from the perennial bioenergy crops short-rotation coppice willow and Miscanthus and the annual arable crops wheat and oilseed rape. GCB Bioenergy. 2016;8:211-25.

54. Fall $\mathrm{R}$, Monson RK. Isoprene emission rate and intercellular isoprene concentration as influenced by stomatal distribution and conductance. Plant Physiol. 1992;100:987-92.

55. Brüggemann N, Schnitzler J-P. Comparison of isoprene emission, intercellular isoprene concentration and photosynthetic performance in waterlimited oak (Quercus pubescens Willd. and Quercus robur L.) Saplings. Plant Biol. 2002;4:456-63. 
56. Dorn E, Hellwig M, Reineke W, Knackmuss HJ. Isolation and characterization of a 3-chlorobenzoate degrading pseudomonad. Arch Microbiol. 1974:99:61-70.

57. Klindworth A, Pruesse E, Schweer T, Peplies J, Quast C, Horn M, et al. Evaluation of general 165 ribosomal RNA gene PCR primers for classical and next-generation sequencing-based diversity studies. Nucleic Acids Res. 2013;41:e1-e1.

58. Illumina. 16S Metagenomic Sequencing Library Preparation Preparing 16S Ribosomal RNA Gene Amplicons for the Illumina MiSeq System Introduction. https://support.illumina.com/documents/documentation/ chemistry_documentation/16s/16smetagenomic-library-prep-guide15044223-b.pdf.

59. Illumina. Nextera XT DNA library prep kit reference guide (15031942). 2019.

60. Callahan BJ, McMurdie PJ, Rosen MJ, Han AW, Johnson AJA, Holmes SP. DADA2: high-resolution sample inference from Illumina amplicon data. Nat Methods. 2016;13:581-3.

61. Maidak BL, Olsen GJ, Larsen N, Overbeek R, McCaughey MJ, Woese CR. The ribosomal database project (RDP). Nucleic Acids Res. 1996;24:82-5. https://doi.org/10.1093/nar/24.1.82.

62. Wood DE, Salzberg SL. Kraken: Ultrafast metagenomic sequence classification using exact alignments. Genome Biol. 2014;15:R46.

63. Lu J, Breitwieser FP, Thielen P, Salzberg SL. Bracken: estimating species abundance in metagenomics data. PeerJ. 2017;1:e104.

64. Uritskiy GV, Diruggiero J, Taylor J. MetaWRAP — a flexible pipeline for genome-resolved metagenomic data analysis. Microbiome. 2018;6:1-13.

65. Kang DD, Li F, Kirton E, Thomas A, Egan R, An H, et al. MetaBAT 2: an adaptive binning algorithm for robust and efficient genome reconstruction from metagenome assemblies. PeerJ. 2019;7:e7359.

66. Wu YW, Simmons BA, Singer SW. MaxBin 2.0: An automated binning algorithm to recover genomes from multiple metagenomic datasets. Bioinformatics. 2016;32:605-7

67. Alneberg J, Bjarnason BS, de Bruijn I, Schirmer M, Quick J, ljaz UZ, et al. Binning metagenomic contigs by coverage and composition. Nat Methods. 2014;11:1144-6.

68. Parks DH, Imelfort M, Skennerton CT, Hugenholtz P, Tyson GW. CheckM: Assessing the quality of microbial genomes recovered from isolates, single cells, and metagenomes. Genome Res. 2015;25:1043-55.

69. Seemann T. Prokka: rapid prokaryotic genome annotation. Bioinformatics. 2014;30:2068-9.

70. Patro R, Duggal G, Kingsford C. Accurate, fast, and model-aware transcript expression quantification with Salmon. bioRxiv. 2015:021592.

71. metaWRAP/Module_descriptions.md at master $\cdot$ bxlab/metaWRAP . GitHub. https://github.com/bxlab/metaWRAP/blob/master/Module_ descriptions.md. Accessed 9 Aug 2021.

72. Carver T, Harris SR, Berriman M, Parkhill J, McQuillan JA. Artemis: an integrated platform for visualization and analysis of high-throughput sequence-based experimental data. Bioinformatics. 2012;28:464-9.

73. Antipov D, Raiko M, Lapidus A, Pevzner PA. Plasmid detection and assembly in genomic and metagenomic data sets. Genome Res. 2019;29:961-8.

74. Rodriguez-R LM, Gunturu S, Harvey WT, Rosselló-Mora R, Tiedje JM, Cole $J R$, et al. The microbial genomes atlas (MiGA) webserver: taxonomic and gene diversity analysis of Archaea and Bacteria at the whole genome level. Nucleic Acids Res. 2018;46:W282-8.

75. Lane DJ. 16S/23S rRNA sequencing. In: Nucleic acid techniques in bacterial systematics. Chichester: Wiley; 1991. p. 115-75.
76. Gupta RS, Lo B, Son J. Phylogenomics and comparative genomic studies robustly support division of the genus Mycobacterium into an emended genus Mycobacterium and four novel genera. Front Microbiol. 2018;9 FEB:67.

77. Murphy GP. Isoprene degradation in the terrestrial environment. University of Essex; 2017.

78. Srivastva N, Shukla AK, Singh RS, Upadhyay SN, Dubey SK. Characterization of bacterial isolates from rubber dump site and their use in biodegradation of isoprene in batch and continuous bioreactors. Bioresour Technol. 2015;188:84-91.

79. Dawson RA, Larke-Mejía NL, Crombie AT, UI Haque MF, Murrell JC Isoprene oxidation by the gram-negative model bacterium Variovorax sp. WS11. Microorganisms. 2020;8:349.

80. Furuya T, Hayashi M, Semba H, Kino K. The mycobacterial binuclear iron monooxygenases require a specific chaperonin like protein for functional expression in a heterologous host. FEBS J. 2013; 280(3):817-26.

81. Sharp JO, Sales CM, LeBlanc JC, Liu J, Wood TK, Eltis LD, et al. An inducible propane monooxygenase is responsible for $\mathrm{N}$ - nitrosodimethylamine degradation by Rhodococcus sp. strain RHA1. Appl Environ Microbiol. 2007:73:6930-8.

82. Kotani T, Yamamoto T, Yurimoto H, Sakai Y, Kato N. Propane monooxygenase and NAD+-dependent secondary alcohol dehydrogenase in propane metabolism by Gordonia sp. strain TY-5. J Bacteriol. 2003;185:7120-8.

83. Furuya $T$, Hirose $\mathrm{S}$, Osanai $\mathrm{H}$, Semba H, Kino K. Identification of the monooxygenase gene clusters responsible for the regioselective oxidation of phenol to hydroquinone in mycobacteria. Appl Environ Microbiol. 2011;77:1214-20.

84. Johnston A. Molecular ecology of marine isoprene degradation. University of East Anglia; 2014

85. Springer AL, Auman AJ, Lidstrom ME. Sequence and characterization of $\mathrm{mxaB}$, a response regulator involved in regulation of methanol oxidation, and of mxaW, a methanol-regulated gene in Methylobacterium extorquens AM1. FEMS Microbiol Lett. 1998;160:119-24.

86. Zhang M, Lidstrom ME. Promoters and transcripts for genes involved in methanol oxidation in Methylobacterium extorquens AM1. Microbiology. 2003; 149:1033-40.

87. Dalton $\mathrm{H}$. The biochemistry of methylotrophs. Trends Biochem Sci. 1983;8:342-3.

88. Hewitt CN, Street RA. A qualitative assessment of the emission of nonmethane hydrocarbon compounds from the biosphere to the atmosphere in the U.K.: present knowledge and uncertainties. Atmos Environ Part A Gen Top. 1992;26:3069-77.

89. Hu B, Jarosch AM, Gauder M, Graeff-Hönninger S, Schnitzler JP, Grote R, et al. VOC emissions and carbon balance of two bioenergy plantations in response to nitrogen fertilization: a comparison of Miscanthus and Salix. Environ Pollut. 2018;237:205-17.

90. Rasmussen RA. Isoprene plant species list. Special report of Air Pollution Research Section. Pullman; 1978.

\section{Publisher's Note}

Springer Nature remains neutral with regard to jurisdictional claims in published maps and institutional affiliations.

Ready to submit your research? Choose BMC and benefit from

- fast, convenient online submission

- thorough peer review by experienced researchers in your field

- rapid publication on acceptance

- support for research data, including large and complex data types

- gold Open Access which fosters wider collaboration and increased citations

- maximum visibility for your research: over 100M website views per year

At BMC, research is always in progress.

Learn more biomedcentral.com/submissions 